\title{
気の病理に関する弁証法的解䣋
}

\section{——気は生体電流であるとるる仮説 —}

木村照

\section{A Dialectic Study of The Pathology of KI, Action Current}

\author{
Akira Kimura \\ (Kobe University)
}

In ancient India, $K i$ was considered Vayu, that was a strong corpuscle. In China, $K i$ was the source of energy. In our country, $K i$ was estimated to be spirit, mind, or electric energy. I consider that $K \mathrm{i}$ is the action current, and is related to the blood circulation and autonomous nervous system.

$K i$ is moving but invisible. It exists only in the living body, not in the dead body. The blood cells move only in the living body, but stop in the dead body. The blood circulation in the body is controlled by the autonomous nervous system. Therefore I hypothesize $K i$ as the action current moving through the autonomous nervous system.

\section{は じめに}

病は気からといらが，気とは一体何であろらか。気は奏在する物質であろらか。それともたんに 人間の空想の産物でしかないのであろらか.このテーマが 4 年前にふとしたことからわたくしの脳 裡に芽生えた.そして診療をはじめとしたあらゆる活動のなかでわたくしはだんだん気を自覚する よらになった.

わたくしたちは日常生活でごく自然に「お元気ですか」とか「お気をつけ下さい」などと気の字 のついた表現を用いている．気の特徵は，生体に対してのみ気の字を用い，死体に対して父の字の 表現を行らことは決してないといらことである. 病気も生体の一状態を意味し, 死体が病父である といった 表現はありえない. 死奴気も生体の一状態であり，死体が死気になることはありえな い. 元気も生体の一状態であり，死体に元気があるとかないとかとはいわない。

病気に関連する気の字の表現は実に多い、気を失う，気が遠くなる，気が沈む…....など枚挙にい とまがない，それほどわたくしたちは日常生活で気のつくことばを頻回に用いている.

わたくしは気を莫然と理解するところから一歩進んで，気を具体的に解明しょうと発起し，その 第一歩として，気は自律神経系を主経路として全身を流れる電流であるとの仮説をたて気の研究に 着手した.

神戸大学医学部耳鼻咽喉科学教室（主任 : 服部 浩教授） 


\section{小説における気}

O・ヘンリ1) の「最後の一葉」には風雨のあ とにも蔦の最後の一葉が残ったため（実はトリ ックであったが)，それをきっかけに気をとり戻 し肺炎を克服した少女の活が出ている.

志賀直哉 ${ }^{2)}$ は「和解」のなかで，子供の急病 に対処するらち，「ウ分は自分の頭痛が何時の 間にか直っているのに気がついた，そしてタ方 までずきずき痛んでいた根太（癖）も今はどう むなくなっていたのに気がついた」と書いてい る.「和解」は全文これ志賀の気の病理で貫か れている気ぜわしい短編小説である.
新田次郎 ${ }^{3)}$ の「赤毛の司天台」には汇户時代, ある浪人者の天気予想がよく当るとい5話が出 てくる．彼は下着の感じで明日の天気が分ると いい，そしてめったに下着は洗わせなかった。 ところが女房を貴ってから天父予想はだめにな ったといら。なぜなら，女房がきれいに乾いた 下着を毎日きせたため，彼の勘が狂ったからで ある。

以上，三編には、人間における父の状況が生さ 生きと描かれている。

\section{気 の 語 源}

気の語源について, 手もとの国語辞典(5)6)を 調べ，第 1 図の如く気を分類した.

気とは第一に外界の状況をいい，自然界では 空気，気圧，気温，気候など，人間社会では䨌 井気，熱気，色気，殺気，などの使い方がある. 第二は生体の内部状況をいい，元気，活気，勇 父，氛合，気力などの用い方がある，第三は 外界と生体との気の交流であり, 気に入る, 気 になる，気を配る，気が通ら，気をとられる， 気をらかがらなどのいい方がある．このように 語源的にみれば，父の字を用いる対象はそれ自 体が運動し，状況が変化する宇宙の存在すべて である.

\section{第1図 気の語源}

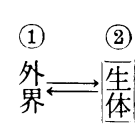

(3)

交

(1) 外界

自然界: 空気, 気仼, 気温, 気候, 寒気

人間社会 : 䨌囲気, 熱気, 色気, 殺気

(2) 生体

元気, 活気, 勇気, 気合, 気力

(3) 交流

気に入る，気になる，気を配る，気が通う．

気をとられる，気をうかがう，

\section{気 の 性 状}

孟子7) は浩然の気をあげ, 荘子 ${ }^{8)}$ は天下を 通じて一気のみといった。

気とは何かについて調べたのが第 1 表であ る. 古代インド医学ススルタ大医典9) のなかに 体内を流通するVayu（神経力）は目に見えな いがあらゆる生命体の成長, 崩壊を決定すると 記載されている.デカルト10) は情念論におい て神経系のなかを運動する動物精気の存在を想 定している. 現在の中医学 ${ }^{11)}$ では気は活動力
の強い精徵物質であり，血液と密接な関係にあ ると定義されている。長浜 ${ }^{12)}$ は気を電気的土 ネルギーと解釈し，土居 ${ }^{13)}$ は瞬間瞬間におけ る精神の動きといい, 赤塚 ${ }^{14)}$ は心から出てい る目に見えない触手と述べた。

このよらに文献的には気は運動する微粒子と してとらえられ，心とは区別されている．辞典 や文献をもとに一般に想定されている気の性状 をまとめると第 2 表の如くである. 
第 1 表 気の解积

\begin{tabular}{l|l|l}
\hline \hline 人 名 & \multicolumn{1}{|c|}{ 文 献 } & \multicolumn{1}{|c}{ 気の 解 釈 } \\
\hline ススルタ & ススルタ大医典 & Vayu (神経力) \\
\hline デカルト & 情念論 & 動物精気 \\
\hline- & 中医学基礎 & 活動力の強い精微物質 \\
\hline 長浜善夫 & 東洋医学概説 & 電気的エネルギー \\
\hline 土居健郎 & 甘えの構造 & $\begin{array}{l}\text { 瞬闈瞬間における精神 } \\
\text { の動き }\end{array}$ \\
\hline 赤塚行雄 & 気の構造 & $\begin{array}{l}\text { 心から出ている目に見 } \\
\text { えない触手 }\end{array}$
\end{tabular}

第 2 表 想定される気の性状
1）目に見えない。
2）生体に内在する.
3）外界（宇宙）に存在する.
4）生体と外界との間で交流する。
5）生体同志で交流する.
6）心と区別される.
7）心と結びついている.
8）血液と関係をもつ。
9）運動する.

\section{気滞について}

東洋医学には血, 気は人体の生理活動の基本 物質であるといら認識がある11)。気は全身を流 通するが，気に関しては気滞といら病理概念が ある. 感情抑麓, 飲食失調, 感染, 外傷などの 原因で気滞（気の流通障害）が起ると, 症状と して局部の疼痛, 腫脹をきたすのである. 頸や 肩のこりも気渔である. 一方, 西洋医学には気 の概念はなく，ここに東西両医学に決定的な立 場の相異が出てくる.

西洋医学にあっては，循環系を流れる血液は 認めるが，神経系を主経路にして全身を流れる 生体電流を病理学的に夕る考方方は確立されて
いない.これは Virchow 以来の病理学が死体 の検索を中心に細胞レベルの病変を視覚的にと らえる立場で発展してきたことと関係が深い。 生体病理の立場で, 病理学者が生体電流の役割 をもっと研究しなければならない。

斎藤 ${ }^{15)}$ は生体磁気学概論のなかで, 磁気が熱 傷治癒を妨げる話や磁気風のとき結核, 高血 圧，心臓病が悪化する話を紹介し，磁気で癌を 発䏍あるいは抑制させる実験を行っている.こ らした研究こそ医学の将来のために高く評価さ れなければならない。

\section{ある症例について}

症例 : 52 才, 男子, 右側頭部腫瘍 (malignant schwannoma)

わたくしが病棟当直で午後 5 時過ざ点滴に迴 ったところ，本患者は 1 週間前から右腕が疼く ので, 左腕飞点滴をしてほしいと訴えた. そこ で, 左肘部の静脈に点滴を行った. そのあと, 右腕の疼く部分を診察しょらとして，わたくし は患者つ訴える右前腕屈側を触診すれば同部の 筋肉は硬く凝っていた。 さらに，わたくしの右 手で同部を揉んだところ，突然に高圧電流に触 れた如くわたくしの右手, 右腕, 右背部, 右頸 部, 右頭部にピリッピリッと激痛が走った. 全
く一瞬の出来事であった．その直後，患者の右 前腕屈側をもら一度触診しなおしてみると筋肉 の硬い凝りはすっかりとれていた．患者は右腕 の痛みが消失し，右半身が軽くなったといっ た。しかし，わたくしはそれから約 2 時間，強 い右偏頭痛を感じた. 数人の同僚医師が本患者 がこの一週間, 右腕の点滴を嫌がることを知っ ていたが，わたくしの体験には半信半疑の表情 であった.

なぜ，わたくしが手で触っただけで，患者の 腕の痛みは一瞬にとれてしまったのであろう か.なぜ，わたくしは強い電流にふれたような 
激痛をおぼえたのであろらか。これは患者とわ たくしにとっては間違いない事実であったが， 科学的に訨明することは困難なことと思えた.

ここで，気は生体電流であるとみる仮説をた て，気滞は生体電流の流通障害といら解釈を行 い, 改めて本患者との間の出来事を考えてみ た.

「右側頭部腫瘍のため右半身に気滞が生じ，そ の結果右前腕に生体電流が過剩に蓄積し，それ が点滴を避けさせる疼痛をひきおこしていた。 当直医が手を触れた結果，蓄䅡していた電流は

考

色不異空 空不異色

色即是空 空即是色

4 年前，祖母の33回忌において般若心経を唱 和した際，「色」と「空」の関係を悟った。 そ のカギは不異の謎が解けたことにある.

色は人間の感覚を介して認識できるもの（物 質）であり，空は色の属性であるが人間の感覚 によっては直接に認識することが困難なもの （電気的エネルギー）をいう. 色と空は対立物 であり，色と空の関係を人間にあてはめると， 色は身体，空は精神となる．また，色は血液， 空は気ともなる。

色一空, 空一色の順序から, 身体が精神の基 礎であるが，精神の身体に対する反作用のある ことも示されている。つまり, 唯物論の観点に 立っている．血液が気（生体電流）の基礎であ るが，気（生体電流）の血液に対する反作用も 示唆されている，身体と精神は弁証法でいら両 側面であり，血液と気もまた并証法でいう両側 面である，血気相和して全身を循環するといら 東洋医学の考方方は従って弁証法的観点をもつ ものである.ここから導き出されることは, 循 環障害と気滞（生体電流の流通障害）がやはり 両側面をなすこと, すなわち両者は共存し, 葛 藤していることである.

哲学的には血液に対応する気（生体電流）あ るいは，循環障害に対する気滞（生体電流の流
一挙に患者から当直医の身体へ流れた. 患者は 気滞がとれて疼痛を忘れ，一方で電流を受けた 当直医は父滞を起し，それが頭痛をひきおこし た.」….と想像した.

第 3 表 気の位置付け

循環系と神経系は全身に分布し，相 互に依存しつつ生体を統一している。

\begin{tabular}{|c|c|}
\hline 循 環 系 & 神経系 \\
\hline 血 液 & 気 \\
\hline
\end{tabular}

察

通障害）の存在が予言できる.それでは，気と か気滞をいかに科学的に証明するか。

もら一度, 般若心経に戻り, 今度は「不異」 と「即是」の意味を考えてみよう. 色と空の関 係は不異と即是によって具体的に解さ明かされ ている. 色不異空（色は空に異ならず）とは一 定条件下での色と空との同一性の関係をいい, 色即是空（色はそのままに空である）とはこれ は矛盾であるため色と空の斗争性の関係をい ら。人間の身体と精神は一個のまとまった生命 体の両側面であり，それが同一性と斗争性の関 係をもつとは身体と精神が相互に相手の存在の 前提となり相互に依存しながら相互に対立する 状沉をいら。このことはわたくしたちが医学・ 医療の世界でしばしばみてきたところであり， 身心医学の根本でもある.

血液と父に和いても同一性と斗争性の関係が 成り立つ. そこで, 気 (生体電流) を研究する ためには血液を手がかりとする道が改めて認識 されてくる．血液循環を調節する役割は自律神 経がになって打り，そらいら密接な関係からい えば, 自律神経の研究のなかにこそ気（生体電 流）の本態を解明するいとぐちがあるといえよ う. 電流には(十)(-)の両側面があるが，自律神経 にも交感神経と副交感神経の両側面がある.わ たくしは以上のような考察を行った結果, 自律 神経のなかを動く生体電流こそ気の中核である 
と感じた。

医学・医療はたえず科学の方向をめざしてい る. 従って，わたくしたちは科学的な態度で医 学・医療のにない手とならなければならない。 しかしながら，今日の科学の水準ではまだ解け ないテーマが沢山ある。例えば，わたくしが患 者の身体に手を触れたら強い電流様の痛久をお ぼえたこともその一つといえる。こうした場
合，哲学の方法を用いて研究方向を打開するこ とは許されるとわたくしは考える. 気というこ とばは日常頻回に使われるが，その使われ方を みると人間行動のらえで重要な役割をもってい る. 気はまた東洋医学の基本概念でもある. 気 の本態が西洋医学の臨床の場を通じて明らかに されたときこそ，数千年の歴史をもつ東西両医 学は真に結びっくとわたくしは考える.

\section{ま と め}

気について考察した結果，東洋医学の父血理論を参考にして，父は血液に対応する生体電流であ るとみる仮説をたてた．生体では血液循環を調節する役割は自律神経がになっているので，気（生 体電流）は自律神経との関係が深いと推定した.

稿を終えるにあたり，服部浩教授の御校閲を感謝します。なお，本論文の要旨は第 42 回耳鼻咽喉科臨床会（昭 和55年) にて発表した.

\section{参考文 献}

1) O. ヘンリ：最後の一葉，O、ヘンリ短編集(3) (大久保康雄訳)

2) 志賀直哉 : 和解, 新潮文庫

3) 新田次郎 : 赤毛の司天台, 横雨将軍信長, 新潮文 庫

4) 金田一京助, 他 : 新明解国語辞典, 三省堂

5 ）金田一京助, 他 : 国語辞典, 三省基

6) 小川環樹, 他 : 新字源, 角川書店

7 ) 孟子: 岩波文庫

8）荘子: 岩波文庫

9）ススルタ大医典 I, II, III, 日本医史学会
10）デカルト：方法序説, 情念論, 中公文庫（野田又 夫訳)

11）上海中医学院編：中医学基碟, 神戸中医学研究会 訳

12）長浜善夫 : 東洋医学概説, 創元社

13) 土居健郎：「甘之」の構造, 弘文堂

14）赤塚行雄：「気」の構造, 講談社

15) 斉藤四郎: 生体磁気学概論, 1975.

$$
\left(\begin{array}{l}
\text { 別刷請求先 : 木村 照 } \\
\text { T } 650 \text { 神戸市中央区楠町 } 7 \text { 丁目 } 12 \\
\text { 神戸大学医学部耳鼻咽喉科学教室 }
\end{array}\right)
$$

